\title{
Sand bluestem and prairie sandreed establishment
}

\section{ROBERT A. MASTERS, KENNETH P. VOGEL, PATRICK E. REECE, AND DENNIS BAUER}

\section{Abstract}

Sand bluestem [Andropogon gerardii var. paucipilus (Nash) Fern,] and prairie sandreed (Calamovilfa longifolia Hook.) are native warm-season grasses used to revegetate cropland and degraded rangeland on highly erodible sandy soils in the central Great Plains. The objectives of this study were to compare establishment success of the 2 grasses and to determine if application of atrazine at time of planting enhanced grass establishment. Eight plantings, including 'Goldstrike' and 'Garden' sand bluestem and 'Goshen' and 'Pronghom' prairie sandreed, were made from 1985 to 1987 at locations in eastern, northcentral, and western Nebraska. Three plantings were established under irrigation and 5 under dryland conditions. Atrazine [6-chloro-N-ethyl-N'-(1-methylethyl)-1,3,5-triazine-2,4-diamine] was applied at a rate of $2.2 \mathrm{~kg}$ a.i./ha at planting at 3 of the dryland sites. Grasses were planted at a rate of $\mathbf{4 3 0}$ pure live seed $/ \mathrm{m}^{2}$ in clean tilled seedbeds. Establishment of sand bluestem, as measured by herbage dry matter yield and/or grass frequency, was generally superior to that of prairie sandreed. Goshen prairie sandreed failed to establish adequate stands in 6 of the 8 plantings. Atrazine, applied at time of planting, increased sand bluestem stand frequency on sites with high weed interference but did not affect that of prairie sandreed. Based on these results, sand bluestem should be a dominant component in seed mixtures used to revegetate and stabilize sandy soils in the central Great Plains.

Key Words: Nebraska Sandhills, rangeland revegetation, reseeding, sand bluestem, Andropogon gerardii var. paucipilus (Nash) Fern., prairie sandreed, Calamovilfa longifolia Hook.

Sand bluestem [Andropogon gerardii var. paucipilus (Nash) Fern.] and prairie sandreed (Calamovilfa longifolia Hook.) are native, sod-forming, warm-season, tallgrasses commonly found on sandy rangeland sites throughout the central Great Plains. The rhizomatous growth characteristic of these grasses enhances stabilization of sandy soils. In the Nebraska Sandhills, these grasses are recognized as key species in grazing programs because of their abundance, yield potential, and complementary distribution of herbage production during the growing season. Prairie sandreed begins growth earlier in the spring, but sand bluestem provides high quality forage longer during the growing season (Burzlaff 1971).

Early settlers in the Nebraska Sandhills found that following cultivation the coarse textured soils soon became unproductive and prone to erosion (Burzlaff 1962). Despite earlier failures, conversion of rangeland to cropland in the Sandhills during the 1970 's was stimulated by high grain prices, prediction of increased demand for grain, and plentiful groundwater that could be applied with center pivot irrigation systems (Miller 1989). Presently, crop

\footnotetext{
Authors are range scientist and supervisory research geneticist, USDA-ARS, Dept of Agronomy, University of Nebraska, Lincoln 68583; associate professor, Department of Agronomy, University of Nebraska, Panhandle Research and Extension Center, and extension agent West Central District.

The authors wish to thank Kevin Grams, Jim Kube, and Gordon Moeller for assistance in completion of this project.

This paper reports the results of research only. Mention of a pesticide in this paper does not constitute a recommendation by the USDA or the University of Nebraska nor does it imply registration under FIFRA.

A contribution of the USDA. Agricuitural Research Service and the University of Nebraska-Lincoln. Published as Paper 9008, Journal Series, Nebraska Agr. Res. Div. Manuscript accepted 8 March 1990
}

production on most of irrigated land in the Sandhills is not profitable. Much of the cropland in this region has been abandoned and designated as highly erodible and suitable for enrollment in the Conservation Reserve Program established by the 1985 Farm Security Act. Consequently, this cropland is in need of revegetation with adapted perennial grasses.

Sand bluestem and prairie sandreed are among the few grasses recommended to revegetate abandoned or highly erodible cropland on sandy soils in the central Great Plains (USDA 1980). Grasses used to revegetate sandy sites must be adapted to the environment and able to establish rapidly to minimize soil erosion. The objectives of this study were to determine which grass was superior for revegetation and stabilization of sandy sites and if application of atrazine at planting enhanced grass establishment.

\section{Materials and Methods}

Eight plantings were made from 1985 to 1987 to compare sand bluestem and prairie sandreed establishment at locations in eastern, northcentral, and western Nebraska (Fig. 1). These locations were chosen to represent the wide diversity of site and climatic

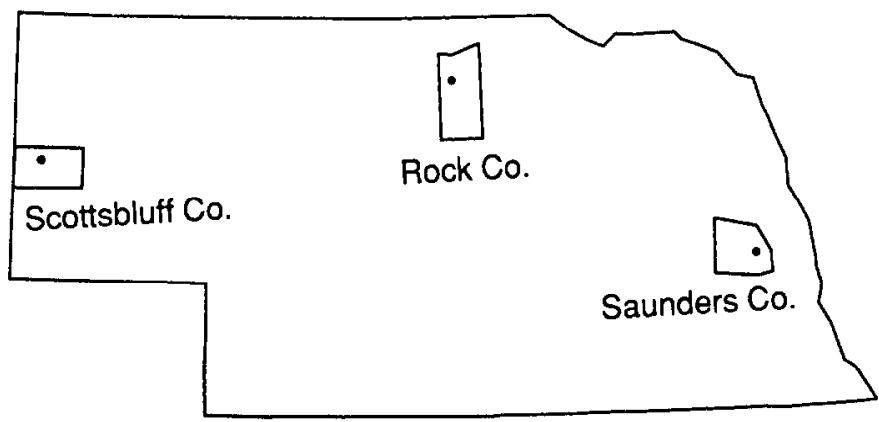

Fig. 1. Location of counties in Nebraska where sand bluestem and prairie sandreed were planted.

conditions encountered in the central Great Plains. Three plantings were established under irrigation and 5 under dryland conditions. Three of the dryland plantings were made to determine the influence of atrazine [6-chloro-N-ethyl-N'-(1-methylethyl)-1,3,5triazine-2,4-diamine], applied at planting, on grass establishment. Each planting represented a separate experiment and was designed as a randomized complete block. Grasses were planted at 430 pure live seed $/ \mathrm{m}^{2}$ in clean tilled seedbeds at a depth of less than $2 \mathrm{~cm}$. Precipitation occurring at each site during the experiments is shown in Figure 2.

\section{Establishment with Irrigation}

Three experiments were conducted where sprinkler irrigation was used during grass establishmenı (Table 1). Experiments 1 and 2 were conducted at the Rock and Brown County Research and Demonstration Farm $7 \mathrm{~km}$ west of Bassett, Neb. The grasses in experiment 1 were planted with a single row cone-drill in plots composed of two, $4.6 \mathrm{~m}$ long rows spaced $30 \mathrm{~cm}$ apart. Plots were mowed and treated with atrazine at 2.2 and $1.1 \mathrm{~kg}$ active ingredient (a.i.)/ ha on 21 May 1986 and 4 June 1987 to reduce weed interference. Grasses evaluated in experiment 2 were planted in $4.6 \times$ $1.2-\mathrm{m}$ plots with a seven-row drill with an $18-\mathrm{cm}$ spacing between rows (Table 1). These plots were mowed then sprayed with $2.2 \mathrm{~kg}$ a.i./ha of atrazine on 4 June 1987. Four replications of each cultivar were planted on each date. Grass stands were irrigated by a 
Table 1. Soil classification, cultivars planted, date of planting, and year vegetation was sampled at sites (counties) where sand bluestem and prairie sandreed were planted in Nebraska.

\begin{tabular}{|c|c|c|c|c|c|c|c|}
\hline \multirow[b]{2}{*}{ Experiment } & \multirow[b]{2}{*}{ Site } & \multicolumn{3}{|c|}{ Soils } & \multirow[b]{2}{*}{ Cultivars $^{2}$} & \multirow{2}{*}{$\begin{array}{l}\text { Planting } \\
\text { Date }\end{array}$} & \multirow{2}{*}{$\begin{array}{c}\text { Sampling } \\
\text { Year }^{3}\end{array}$} \\
\hline & & Series & Texture $^{\mathrm{l}}$ & Classification & & & \\
\hline \multicolumn{8}{|c|}{ Established with irrigation } \\
\hline 1 & Rock & Valentine & $\mathbf{s}$ & $\begin{array}{l}\text { Mixed, mesic, } \\
\text { Typic Ustipsamment }\end{array}$ & GS, GO, PN & 6 June 1985 & 1987 \\
\hline 2 & Rock & Valentine & $\mathbf{s}$ & $\begin{array}{l}\text { Mixed, mesic, } \\
\text { Typic Ustipsamment }\end{array}$ & GS, GA, GO, PN & 21 May 1986 & $1987^{4}$ \\
\hline 3 & Scottsbluff & Tripp & sl & $\begin{array}{l}\text { Mixed, mesic, } \\
\text { Typic Haplustoll }\end{array}$ & GS, GA, GO, PN & 23 May 1986 & 1987 \\
\hline \multicolumn{8}{|c|}{ Dryland establishment } \\
\hline 4 & Rock & Valentine & $\mathbf{s}$ & $\begin{array}{l}\text { Mixed, mesic, } \\
\text { Typic Ustipsamment }\end{array}$ & GS, GA, GO, PN & 4 June 1987 & 1988 \\
\hline 5 & Saunders & Ortello & sl & $\begin{array}{l}\text { Mixed, mesic, } \\
\text { Udic Haplustoll }\end{array}$ & GS, GA, GO, PN & 15 May 1986 & 1987 \\
\hline \multicolumn{8}{|c|}{ Dryland establishment with atrazine } \\
\hline 6 & Rock & Valentine & s & $\begin{array}{l}\text { Mixed, mesic, } \\
\text { Typic Ustipsamment }\end{array}$ & GS, GO & 21 May 1986 & 1987 \\
\hline 7 & Rock & Valentine & $\mathbf{s}$ & $\begin{array}{l}\text { Mixed, mesic, } \\
\text { Typic Ustipsamment }\end{array}$ & GS, GO & 4 June 1987 & 1988 \\
\hline 8 & Saunders & Sharpsburg & sicl & $\begin{array}{l}\text { Fine, montmorillonitic } \\
\text { Typic Argiudoll }\end{array}$ & GS, GO & 13 May 1986 & 1987 \\
\hline
\end{tabular}

ISoil textures are sand (s), sandy loam (sl), and silty clay loam (sicl).

2Cultivars planted were "Goldstrike' sand bluestem (GS), 'Garden' sand bluestem (GA), 'Goshen' prairie sandreed (GO), and 'Pronghorn' prairie sandreed (PN).

'Year herbage dry matter yield and frequency of planted grasses were determined.

${ }^{4}$ Herbage dry matter yield not determined.

$\times 75-\mathrm{cm}$ metal frame partitioned into twenty-five, $15 \times 15-\mathrm{cm}$ portions (Vogel 1987). The metal frame was placed over the center row at 2 locations within each plot and number of $15 \times 15-\mathrm{cm}$ portions containing at least 1 seeded grass was recorded. In experiments 6,7 , and 8 the occurrence of at least 1 of the seeded grasses in $20,5 \mathrm{~cm}$ long by $18 \mathrm{~cm}$ wide portions was recorded along 4 randomly selected 1-m row segments (Sampson and Moser 1982, Griffin et al. 1988). Using a quadrat sub-divided into several units measured local frequency (Kershaw and Looney 1985).

Herbage yield and grass frequency measurements taken 1 or 2 years after seeding were used to evaluate establishment of sand bluestem and prairie sandreed. Since experiments 1 through 5 were designed as separate experiments and location effects in experiments 6,7 , and 8 were significant $(R<0.10)$, herbage yield and grass frequency data from each experiment were analyzed separately using the general linear model procedures within the Statistical Analysis System (SAS) (SAS Institute Inc. 1985). Orthogonal contrasts and F-tests were used to evaluate treatment effects and Fischer's protected LSD $(P<0.05)$ was used to compare treatments means in experiments 6,7 , and 8 .

\section{Results and Discussion}

\section{Establishment with Irrigation}

These studies were conducted because sprinkler irrigation systems often remain operable on abandoned or highly erodible cropland sites until perennial grasses are established. Sand bluestem established better stands than prairie sandreed at all irrigated sites (Table 2). Launchbaugh (1966) and Launchbaugh and Owensby

Table 2. Mean herbage dry matter yield (YLD) and frequency (FREQ) of sand bluestem and prairie sandreed cultivars planted on irrigated sites in Scottsbluff County Nebraska in 1986 and Rock County Nebraska in 1985 and 1986 and harvested in 1987.

\begin{tabular}{|c|c|c|c|c|c|c|}
\hline \multirow[b]{3}{*}{ Species Cultivars } & \multicolumn{6}{|c|}{ Location and Year of Planting } \\
\hline & \multicolumn{2}{|c|}{$\begin{array}{c}\text { Rock Co. } \\
1985\end{array}$} & \multicolumn{2}{|c|}{$\begin{array}{c}\text { Rock Co. } \\
1986\end{array}$} & \multicolumn{2}{|c|}{$\begin{array}{c}\text { Scottsbluff Co. } \\
1986 \\
\end{array}$} \\
\hline & YLD & FREQ' & YLD & FREQ & YLD & FREQ \\
\hline Sand bluestem (SDB) & & $-\%$ & $-\mathrm{kg} / \mathrm{ha}-$ & $-\%$ & $-\mathrm{kg} / \mathrm{ha}-$ & $-\%-$ \\
\hline $\begin{array}{l}\text { 'Goldstrike' (GS) } \\
\text { Garden'(GA) }\end{array}$ & $\begin{array}{l}5075 \\
\mathrm{NP}^{3}\end{array}$ & $\begin{array}{l}82 \\
\text { NP }\end{array}$ & $\begin{array}{l}\mathrm{NH}^{2} \\
\mathrm{NH}\end{array}$ & $\begin{array}{l}33 \\
43\end{array}$ & $\begin{array}{l}3061 \\
4009\end{array}$ & $\begin{array}{l}91 \\
91\end{array}$ \\
\hline $\begin{array}{l}\text { Prairie sandreed (PSR) } \\
\text { 'Goshen'(GO) } \\
\text { 'Pronghorn'(PN) }\end{array}$ & $\begin{array}{l}\text { NH } \\
\text { NH }\end{array}$ & $\begin{array}{r}5 \\
11\end{array}$ & $\begin{array}{l}\text { NH } \\
\text { NH }\end{array}$ & $\begin{array}{l}6 \\
9\end{array}$ & $\begin{array}{l}2196 \\
2905\end{array}$ & $\begin{array}{l}70 \\
58\end{array}$ \\
\hline Contrasts & & & ysis of var & st probat & & \\
\hline $\begin{array}{l}\text { SDB vs. PSR } \\
\text { GS vs. GA } \\
\text { GO vs. PN }\end{array}$ & $\bar{z}$ & $\begin{array}{l}0.01 \\
\overline{0.58}\end{array}$ & $\begin{array}{l}- \\
-\end{array}$ & $\begin{array}{l}0.01 \\
0.36 \\
0.79\end{array}$ & $\begin{array}{l}0.11 \\
0.23 \\
0.35\end{array}$ & $\begin{array}{l}0.01 \\
0.97 \\
0.14\end{array}$ \\
\hline
\end{tabular}

IA conservative estimate of the number of plants per square meter can be obtained by multiplying stand percentage by 0.4 .

${ }^{2} \mathrm{NH}=$ not harvested.

${ }^{3} \mathrm{NP}=$ not planted. 
Table 3. Mean herbage dry matter yield (YLD) and frequency (FREQ) of sand bluestem and prairie sandreed cultivars planted on dryland sites in Saunders County Nebraska in 1986 and Rock County Nebraska in 1987 are harvested in 1987 and 1988, respectively.

\begin{tabular}{|c|c|c|c|c|}
\hline \multirow[b]{3}{*}{ Species cultivars } & \multicolumn{4}{|c|}{ Location and Year of Planting } \\
\hline & \multicolumn{2}{|c|}{$\begin{array}{c}\text { Saunders Co. } \\
1986 \\
\end{array}$} & \multicolumn{2}{|c|}{$\begin{array}{c}\text { Rock Co. } \\
1987 \\
\end{array}$} \\
\hline & YLD & $\overline{\text { FREQ }^{1}}$ & YLD & FREQ \\
\hline Sand bluestem (SDB) & -kg/ha- & $-\%-$ & $-\mathrm{kg} / \mathrm{ha}-$ & $-\%$ \\
\hline $\begin{array}{l}\text { 'Goldstrike' (GS) } \\
\text { Garden' (GA) }\end{array}$ & $\begin{array}{l}2834 \\
3769\end{array}$ & $\begin{array}{l}63 \\
74\end{array}$ & $\begin{array}{l}2224 \\
2423\end{array}$ & $\begin{array}{r}98 \\
100^{-}\end{array}$ \\
\hline $\begin{array}{l}\text { Prairie sandreed (PSR } \\
\text { 'Goshen'(GO) } \\
\text { 'Pronghorn'(PN) }\end{array}$ & $\begin{array}{r}109 \\
1498\end{array}$ & $\begin{array}{r}8 \\
30\end{array}$ & $\begin{array}{l}216 \\
385\end{array}$ & $\begin{array}{l}13 \\
48\end{array}$ \\
\hline Contrasts & \multicolumn{4}{|c|}{ Analysis of variance F-test probabilities } \\
\hline $\begin{array}{l}\text { SDB vs. PSR } \\
\text { GS vs. GA } \\
\text { GO vs. PN }\end{array}$ & $\begin{array}{l}0.01 \\
0.28 \\
0.35\end{array}$ & $\begin{array}{l}0.01 \\
0.10 \\
0.01\end{array}$ & $\begin{array}{l}0.01 \\
0.62 \\
0.51\end{array}$ & $\begin{array}{l}0.01 \\
0.68 \\
0.01\end{array}$ \\
\hline
\end{tabular}

A conservative estimate of the number of plants per square meter can be obtained by multiplying stand percentage by 0.4 .

(1970) reported that 10 to 20 plants $/ \mathrm{m}^{2}$, comparable with 25 to $50 \%$ stands in these experiments, were needed for grass establishment to be considered a success in the central Great Plains. Based upon these criteria, all of the irrigated sand bluestem plantings were successful, but prairie sandreed was only successfully established in experiment 3. Weed interference and rust-induced reduction in plant vigor may partially explain poor prairie sandreed stands and yields in experiments 1 and 2 . Frequent irrigation during the late spring and summer of 1985,1986 , and 1987 promoted weed growth and could have favored rust development. Irrigation probably hindered rather than enhanced prairie sandreed establishment in these experiments.

\section{Dryland Establishment}

Sand bluestem stands were better than prairie sandreed stands in experiments 4 and 5 , regardless of cultivar (Table 3). According to grass stand establishment criteria developed by Launchbaugh (1966), sand bluestem established successfully at both sites. Yield of Pronghorn prairie sandreed was similar to Goldstrike sand bluestem in Saunders County, but it was less than both sand bluestem cultivars in Rock County. Low yield and poor stand establishment of Goshen prairie sandreed probably resulted from low plant vigor caused by rust infestation. Regardless of heavily infested with rust than Goshen prairie sandreed on the dryland sites as compared to Pronghorn prairie sandreed or the 2 sand bluestem cultivars (data not shown). Pronghorn prairie sandreed was found to be less susceptible to rust (Puccinia amphigea) infection than Goshen prairie sandreed (Anonymous 1988). Pronghorn prairie sandreed plantings were successful, but yielded only 16 to $53 \%$ as much as the sand bluestem cultivars (Table 3 ).

\section{Dryland Establishment with Atrazine}

These studies were conducted because sand bluestem may be tolerant to atrazine applied at time of planting. The herbicide product label indicates that atrazine can be applied to big bluestem (Andropogon gerardii Vitman var. gerardii Vitman), of which sand bluestem is a botanical variety (Stubbendieck et al. 1985), at time of planting. Atrazine reduces weed interference and enhances establishment of tolerant warm-season perennial grasses (Martin et al. 1982).

Sand bluestem frequency of occurrence was generally greater than that of prairie sandreed in experiments 6,7 , and 8 , (Table 4). According to Launchbaugh's (1966) criteria for successful grass establishment, i.e., 10 to 20 plants $/ \mathrm{m}^{2}$, which is comparable to 20 to $40 \%$ stands in these experiments, all sand bluestem plantings were successful, except for experiment 6 where atrazine was not applied at planting. In contrast, acceptable stands of prairie sandreed were established only in experiment 7 .

Herbage yield of sand bluestem exceeded prairie sandreed only when atrazine was applied at planting in experiments 6 and 8 . However, sand bluestem consistently established better stands and yielded more than prairie sandreed in experiment 7 where grasses were planted in 1987, regardless of atrazine treatment.

Establishment of prairie sandreed appeared to be unaffected by atrazine application. Bahler et al. (1984) reported that prairie sandreed survival decreased following applications of $1.1,2.2$, and $3.4 \mathrm{~kg} \mathrm{a.i./ha}$ of atrazine the year of planting when compared to untreated plants. They ranked prairie sandreed seedlings intermediate in tolerance to atrazine. In our study, the differential response of sand bluestem and prairie sandreed to atrazine may have been caused by inherent differences in seedling vigor and tolerance to the herbicide.

Differences between yield and frequency of grasses planted in experiments 6 and 7 probably resulted from different levels of weed

Table 4. Mean herbage dry matter yield (YLD) and frequency (FREQ) of 'Goldstrike' sand bluestem (SDB) and 'Goshen' prairie sandreed (PSR) planted on dryland sites with and without preemergence atrazine application in Saunders County Nebraska in 1986 and Rock County Nebraska in 1986 and 1987 and harvested the year after planting.

\begin{tabular}{|c|c|c|c|c|c|c|c|}
\hline \multirow[b]{3}{*}{ Species } & \multirow{3}{*}{$\begin{array}{c}\text { Atrazine } \\
\text { Rate }\end{array}$} & \multicolumn{6}{|c|}{ Location and Year of Planting } \\
\hline & & \multicolumn{2}{|c|}{$\begin{array}{c}\text { Saunders Co. } \\
1986\end{array}$} & \multicolumn{2}{|c|}{$\begin{array}{c}\text { Rock Co. } \\
1986\end{array}$} & \multicolumn{2}{|c|}{$\begin{array}{c}\text { Rock Co. } \\
1987\end{array}$} \\
\hline & & YLD & FREQ $^{\prime}$ & YLD & FREQ & YLD & FREQ \\
\hline $\begin{array}{l}\text { SDB } \\
\text { SDB } \\
\text { PSR } \\
\text { PSR } \\
\text { LSD }(0.05)^{2}\end{array}$ & $\begin{array}{c}-\mathrm{kg} / \mathrm{ha} \\
0 \\
2.2 \\
0 \\
2.2\end{array}$ & $\begin{array}{c}-\mathrm{kg} / \mathrm{ha}- \\
1631 \\
10733 \\
547 \\
1148 \\
4331\end{array}$ & $\begin{array}{c}-\%- \\
35 \\
58 \\
18 \\
10 \\
\text { NS }\end{array}$ & $\begin{array}{c}-\mathrm{kg} / \mathrm{ha}- \\
97 \\
1908 \\
10 \\
17 \\
1251\end{array}$ & $\begin{array}{c}-\%- \\
10 \\
43 \\
0 \\
3 \\
9\end{array}$ & $\begin{array}{c}-\mathrm{kg} / \mathrm{ha}- \\
5107 \\
4692 \\
794 \\
1231 \\
\text { NS }\end{array}$ & $\begin{array}{c}-\%- \\
50 \\
56 \\
26 \\
25 \\
\text { NS }\end{array}$ \\
\hline Treatment effects & & \multicolumn{6}{|c|}{ Analysis of Variance F-test probabilities } \\
\hline $\begin{array}{l}\text { Species (S) } \\
\text { Herbicide Rate (HR) } \\
\mathrm{S} \times \text { HR }\end{array}$ & & $\begin{array}{l}0.17 \\
0.05 \\
0.07\end{array}$ & $\begin{array}{l}0.08 \\
0.01 \\
0.12\end{array}$ & $\begin{array}{l}0.12 \\
0.09 \\
0.09\end{array}$ & $\begin{array}{l}0.01 \\
0.01 \\
0.01\end{array}$ & $\begin{array}{l}0.02 \\
0.17 \\
0.97\end{array}$ & $\begin{array}{l}0.01 \\
0.50 \\
0.42\end{array}$ \\
\hline
\end{tabular}

'A conservative estimate of the number of plants per square meter can be obtained by multiplying stand percentage by 0.5 .

${ }^{2}$ Critical values for comparison of treatment means obtained using Fisher's protected LSD where $P \geq 0.05$ and $6 \mathrm{df}$. 
interference the year of seeding. The site planted in 1986 supported a poor stand of low vigor alfalfa (Medicago sativa $\mathrm{L}$.) and smooth brome (Bromus inermis Leyss.) that was heavily infested with annual broadleaf and grass weeds prior to seedbed preparation. In contrast, the site planted in 1987 probably had less residual weed seed than the site seed in 1986 because it previously supported a native perennial grass community at a late seral stage with few weeds. The effect of weed interference, resulting from residual weed seed, on the establishment of sand bluestem and prairie sandreed is apparent in the positive response of sand bluestem stand to atrazine in 1986 but not in 1987.

Sand bluestem establishment, as measured by stand and/or yield, was superior to that of prairie sandreed on several irrigated and dryland sites in Nebraska. The wide diversity of sites used in these experiments encompass most environmental conditions encountered on sandy sites in the central Great Plains. Based on these findings, sand bluestem should be the dominant component in seed mixtures used to revegetate and stabilize sandy soils in the central Great Plains. Despite poor establishment, prairie sandreed should remain a minor component of seed mixtures planted on these sites because upon establishment it effectively stabilizes sandy soils and it is of ecological significance as a co-dominant in sandy rangeland plant communities (Burzlaff 1962).

Atrazine can be applied when sand bluestem is planted if severe weed interference is anticipated. Most sandy sites requiring revegetation will be abandoned or marginal cropland at an early seral stage, so significant weed interference should be expected. This research indicates that atrazine had no effect on prairie sandreed establishment. Bahler et al. (1984) indicates that prairie sandreed seedlings have an intermediate tolerance to atrazine so it may be of use to reduce weed interference. However, research is needed to determine appropriate rate(s) and time(s) of application. Based on current information, atrazine should not be applied at time of planting when prairie sandreed is a component of the seed mixture to be planted.

\section{Literature Cited}

Anonymous. 1988. Notice of release of 'PRONGHORN' prairie sandreed. USDA-ARS, USDA-SCS, and Nebraska Agr. Exp. Sta. Lincoln.

Bahler, C.C., K.P. Vogel, and L.E. Moser. 1984. Atrazine tolerance in warm-season grass seedlings. Agron. J. 76-891-895.

Burzlaff, D.F. 1962. A soil and vegetation inventory and analysis of three Nebraska sandhills range sites. Nebraska Agr. Exp. Sta. Res. Bull. 206.

Burzlaff, D.F. 1971. Seasonal variations of the in vitro dry-matter digestibility of three sandhills grasses. J. Range Manage. 24:60-63.

Goldsmith, F.B., and C.M. Harrison. 1976. Description and analysis of vegetation. p. 85-155. In: S. B. Chapman (ed), Methods in plant ecology. Halstead Press, New York.

Griffin, T.S., L.E. Moser, and A.R. Martin. 1988. Influence of antidotes on forage grass seedling response to metolachlor and butylate. Weed Sci. 36:202-206.

Kershaw, K.A., and J.H.H. Looney. 1985. Quantitative and dynamic plant ecology. Edward Arnold Pub. Ltd. London, England.

Launchbaugh, J.L. 1966. A stand establishment survey of grass plantings in the Great Plains. Nebraska Agr. Exp. Sta. Great Plains Council Pub. 23.

Launchbaugh, J.L., and C.E. Owensby. 1970. Seeding rate and first year stand relationships for six native grasses. J. Range Manage. 23:414-417.

Martin, A.R., R.S. Moomaw, and K.P. Vogel. 1982. Warm-season grass establishment with atrazine. Agron. J. 74:916-920.

Miller, S.M. 1989. Land development and use. p. 207-226. In: A. Bleed and C. Flowerday (eds.), An atlas of the Sand Hills. Resource Atlas No. 5. Conserv. Survey Div. Univ. Nebraska, Lincoln.

SAS Institute Inc. 1982. SAS user's guide: Statistics. SAS Institute Inc. Cary, N.C.

Samson, J.F., and L.E. Moser. 1982. Sod-seeding perennial grasses into eastern Nebraska pastures. Agron. J. 74:1055-1060.

Stubbendieck, J., J.T. Nichols, and K.K. Roberts. 1985. Nebraska range and pasture grasses. Nebr. Coop. Ext. Serv. EC 85-170.

USDA. 1980. Range seeding. Nebraska Technical Guide Notice 110 USDA-SCS. Lincoln, Nebr.

Vogel, K.P. 1987. Seeding rates for establishing big bluestem and switchgrass with preemergence atrazine applications. Agron. J. 79:509-512.

Your Computer, helpful though it be, can never eliminate the need for a good personal library of professional publications. Contact the Society headquarters for a list of available publications on the art and science of range management. Write to 1839 York Street, Denver, Colorado 80206 or call (303) 355-7070. 